Kalina Jastrzębowska

https://doi.org/10.26881/pwe.2018.42.12

ORCID: 0000-0002-0973-9501

University of Warsaw

kw.jastrzebows@student.uw.edu.pl

\title{
The power of dialogue and discovery
}

\begin{abstract}
Summary
Greater emphasis must be placed on activities that promote innovative teaching methods in early childhood mathematics education in Poland. Our classrooms offer algorithmic and rote teaching methods, depriving students of important elements of successful mathematics learning. The aim of this action research was to investigate the relationship between a classroom environment that allows for dialogue and discovery and young children's input into problem solving. Teaching six classes of elementary school within one academic year gave the author the opportunity to examine how dialogic teaching combined with a growth mindset approach can transform the attainment of knowledge, understanding and skills of learners, and how modern practices like number talks, solving open-ended tasks and group work can unleash students' potential and activate them as thinkers and reasoners. The results confirmed that students who are challenged and offered concept-based learning opportunities not only genuinely engage in their tasks, but also help each other with deeper understanding of the concepts. They can cooperate with teachers in the creation of a new classroom in which students' voices are heard and discoveries take place.
\end{abstract}

Keywords: dialogic teaching, growth mindset, modern practices in early childhood mathematics education, students' voices

\section{Introduction}

\section{Dialogic teaching}

As Cambridge educator and dialogic teaching campaigner Robin Alexander stated, dialogic teaching should be collective, reciprocal, supportive, cumulative and purposeful (Alexander 2017: 27-28). The effective intertwinement of these qualities and implementation of the principles that they represent results in a safe classroom environment, where students feel confident and free to express their ideas, without fear of embarrassment or other negative emotions experienced when the concept of "wrong answers" is enforced. It is key that students and teachers alike coexist as participants and contributors of the discourse community, building on their own and others' ideas along the path towards set learning goals. According to Alexander's research results, there is a direct relationship between dialogic teaching and development of cognitive reasoning ability. Individual and collective academic outcomes are supported by collaborative sense-making in discussion. Exchanging ideas and resolving disagreements mobilizes participants to absorb each 
other's viewpoints and to achieve a new understanding. This process is also important in a social and emotional context.

In the modern history of mathematics, there have been many people who have pointed to the importance of the genuine engagement of learners within academic community.

The work and philosophical findings of many mathematicians can inspire subject teachers to deepen their understanding of their own role in the classroom. Imre Lakatos (1922-1974), in his Proofs and Refutations, makes a clear distinction between two approaches to teaching mathematics (see Table 1).

Table 1. Lakatos's recognition of two opposing approaches towards teaching mathematics (Lakatos 1976: 5)

\begin{tabular}{|l|l|}
\hline \multicolumn{1}{|c|}{ Deductivist Approach to Mathematics } & \multicolumn{1}{c|}{ Heuristic Approach to Mathematics } \\
\hline $\begin{array}{l}\text { Based on Euclidean methodology - treats } \\
\text { mathematics ("the proud fortress of } \\
\text { dogmatism") as a set of eternal, immutable } \\
\text { truths }\end{array}$ & $\begin{array}{l}\text { Based on the assumption that mathematics is } \\
\text { a product of human mathematical activity and } \\
\text { so it cannot be "authoritative, infallible and } \\
\text { irrefutable" }\end{array}$ \\
\hline $\begin{array}{l}\text { Students accept presented knowledge, do } \\
\text { not ask questions and follow procedures } \\
\text { (knowledge to be taught and to be learned) }\end{array}$ & $\begin{array}{l}\text { Students take part in discovering knowledge in } \\
\text { the social context in which it was created and } \\
\text { where it is used }\end{array}$ \\
\hline $\begin{array}{l}\text { The ideal background for Traditional Teaching } \\
\text { of mathematics (term used by modern scholars) }\end{array}$ & $\begin{array}{l}\text { The ideal background for Dialogic Teaching of } \\
\text { mathematics (term used by modern scholars) }\end{array}$ \\
\hline
\end{tabular}

Another philosopher that recognised deductivist and heuristic presentations of mathematics was George Pólya (1887-1985). In his famous book, entitled How to solve it, he discusses the art of guessing in mathematics and suggests the use of induction and analogy as two sources of plausible reasoning. He also proposes a model for teaching mathematics based on the relationship between a student and an experienced teacher - a provider of stimulating questions in the process of problem solving. Pólya encourages teachers to offer challenging tasks to their students and to enable them to experience the "triumph of discovery." He addresses the importance of independent thinking at any stage of learning and discusses the necessity of inventing new problems by a mathematician of any age (Pólya 1988: 205-206).

\section{Growth Mindset in Mathematics}

Inspiration for primary school teachers' endeavours in implementing the new method of mathematics teaching can be found in the approach defined by Stanford University Professor Jo Boaler. The approach is described in detail in her book Mathematical Mindsets. Cooperating with subject teachers and psychologist Carol Dweck, Boaler conducted research on emotions and motivation in mathematics. She found that through the enjoyment of mathematics as an open, intriguing subject, full of multiple solutions, students' approach towards learning changed, their motivation flourished, and their results improved greatly. Important elements of the growth mindset approach that can be used and implemented in the classroom are summed up in Table 2. 
Table 2. A summary of Dweck's Fixed vs. Growth Mindset distinction (Dweck 2017) and Boaler's implementation suggestions (Boaler 2016)

\begin{tabular}{|c|c|c|c|}
\hline $\begin{array}{c}\text { Elements of } \\
\text { approach }\end{array}$ & Fixed Mindset & Growth Mindset & $\begin{array}{c}\text { How to implement the growth } \\
\text { mindset in the classroom }\end{array}$ \\
\hline $\begin{array}{c}\text { Intellect / } \\
\text { talents }\end{array}$ & are static & can be developed & $\begin{array}{c}\text { praise for being active / offering } \\
\text { creative solutions }\end{array}$ \\
\hline Challenges & avoided & embraced & make sure the tasks are not too easy \\
\hline Feedback & ignored & helpful & use A4L (Assessment for learning) \\
\hline Failure & the end of the world & a turning point & celebrate good mistakes \\
\hline Reflection & not used & $\begin{array}{c}\text { used as a learning } \\
\text { tool }\end{array}$ & discuss goals \\
\hline Effort & seen as fruitless & $\begin{array}{c}\text { seen as a path to } \\
\text { mastery }\end{array}$ & $\begin{array}{c}\text { help to understand the necessity to } \\
\text { struggle }\end{array}$ \\
\hline $\begin{array}{c}\text { Success of } \\
\text { others }\end{array}$ & threatening & Inspiring & celebrate \\
\hline
\end{tabular}

Building a growth mindset in the classroom is necessary for students' success. According to research conducted by Boaler and Zaido, the results of PISA tests in mathematics are closely related to the quality of students' mindset beliefs (Boaler 2016: 7). PISA results also show that mathematics should be taught as a set of ideas, not a set of methods, and that memorizers are low achievers.

\section{Modern Practices}

Certain classroom practices are common for both Growth Mindset Maths and Dialogic Teaching, and it is necessary for primary school teachers to be aware of them. These practices include:

- Keeping alive possibilities for new ways of seeing;

- Respecting new perspectives;

- Encouraging risk taking;

- Giving space for asking questions / learning how to ask good questions;

- Providing challenges;

- Providing opportunities for critical thinking and creative reasoning;

- Honouring mistakes.

Additionally, teachers need to pay more attention to the aspect of language. They can motivate their students to build growth mindset vocabulary by creating metaphors and similes, such as "Challenges are brain food" or "Feedback is your friend" (Gershon 2016: 39 ) and by asking questions promoting growth mindsets, e.g. "What makes a good mistake?" (Gershon 2016: 143-149).

\section{Meanwhile in Our Classrooms}

Much encouragement and support are needed to aid primary school teachers in Poland in absorbing and implementing alternative teaching strategies. Research conducted on early childhood mathematics education in Poland between 2006-2011 by M. Dąbrowski 
and M. Żytko (University of Warsaw, published in (Za) trudne, bo trzeba myśleć, 2016) indicated that areas requiring the most assistance are: communication, group work, visualization, creativity and solving open-ended tasks. All of the elements that dominate the majority of Polish classrooms - lecturing to passive students, too much time spent by pupils on practicing methods presented to them by their teachers, computational skills regarded as the most useful of all for student success, lack of creative tasks - go against both the growth mindset approach and dialogic teaching.

\section{Methods}

\section{Dialogic teaching activities}

As I became involved in action research, I began paying more attention to the power of children's voices. I could see that engaging the students in dialogue and giving them opportunities to discover concepts on their own is the only way to enhance their mathematical enthusiasm. At the same time, I realized that it is crucial to be aware of the benefits and dangers of using different types of activities in dialogic teaching. Some of my observations have been summarised in Table 3 .

Table 3. Findings of the author's action research

\begin{tabular}{|c|c|c|}
\hline $\begin{array}{c}\text { Activities in dialogic } \\
\text { teaching-examples }\end{array}$ & Benefits & Dangers \\
\hline $\begin{array}{c}\text { Whole-class learning } \\
\text { (number talk) }\end{array}$ & $\begin{array}{c}\text { Sharing ideas; } \\
\text { precise subject language }\end{array}$ & $\begin{array}{c}\text { Intimidating set-up for } \\
\text { shy students }\end{array}$ \\
\hline $\begin{array}{c}\text { Group work } \\
\text { (open-ended tasks) }\end{array}$ & $\begin{array}{c}\text { Fuller engagement; } \\
\text { language development }\end{array}$ & $\begin{array}{c}\text { Less productive, } \\
\text { off-task activities }\end{array}$ \\
\hline $\begin{array}{c}\text { Teacher-led explorations } \\
\text { in groups (real life } \\
\text { word problems) }\end{array}$ & All of the above & $\begin{array}{c}\text { Less freedom for students who } \\
\text { are able to focus on the task }\end{array}$ \\
\hline
\end{tabular}

Number talks are short exercises, up to 15 minutes in duration, aimed at building number sense (visualizing problem solving, performing calculations in many ways, becoming flexible in strategy search, checking if answers make sense) that allow students to discuss mathematics in their own ways (Humphreys 2015: 5). They can be performed as a whole class or as a group activity.

Group work is supposed to be designed for groups of mixed ability. Each group participant should have a special role assigned, groups can be remodelled, and new roles can be offered to students every few weeks. The teacher's job is not only to orchestrate group work, but also to recognise students' competences and to praise individual efforts as well as to teach the pupils the value of feedback as an important aspect in gaining mathematical knowledge (Boaler 2016: 132-140).

Open-ended tasks (sometimes called ill-structured or incomplete tasks) are problems with multiple solutions or with more than one solving strategy. As Finnish mathematics 
educator Erkki Pehkonen stated: "Tasks are said to be open if their starting or goal situation is not exactly given" (Pehkonen 1999). They were first developed in Japan in the 1970 s but are now internationally recognized as a teaching tool that reinforces understanding and creativity.

All of the lessons that I taught took place in a private school in Warsaw, Poland, which offers the International Baccalaureate programme. Mathematics instruction in this educational institution is conducted in English, although the school is a bilingual environment, so it is not unusual for the Polish language to also be present in the classroom. Lessons that were taught within the 2017-18 school year were carefully reflected on, notes and photographs were taken whenever a striking moment was noticed.

I taught six different classes (five lessons per week each) from Year 1 to Year 4 (ages 6 through 10):

- Year 1: 16 students ( 8 girls, 8 boys);

- Year 2A: 12 students (4 girls, 8 boys) 2B: 14 students (4 girls, 10 boys);

- Year 3A: 13 students (3 girls, 10 boys) 3B: 15 students (5 girls, 10 boys);

- Year 4: 18 students (8 girls, 10 boys).

Preparing challenging tasks for my students, I believed in their power to tackle such problems. I created a listening environment in the classroom; the students knew that their contribution was always welcome. Originally, I wanted to focus on the process of problem solving in my observations, but I quickly replaced it with focusing on the attainment of understanding, knowledge and skills. The learners taught me many new ways to approach mathematical assignments; they truly proved themselves to be both thinkers and reasoners.

\section{Results}

Below I would like to present some examples of tasks that were solved by my elementary school students. I was not only frequently amazed by the richness of their understanding of the concepts, but also thankful for each person's contribution and for showing me a new perspective.

\section{Number talks - whole class activity}

Each example (Tables 4-6) was discussed with the whole class with the students reacting spontaneously to other pupils' ideas. The first child showed his idea of adding and later subtracting the same number on the number line. He also made a reference to a financial situation of borrowing some money and returning it later.

The second situation (Table 5) gave us the perfect pretext to initiate a discussion about negative numbers. Many students liked the idea so much that they decided to talk about this method of subtraction at home.

The third example (Table 6) was interesting as it initiated the discussion about the nonchanging distance between two numbers travelling along a number line. 
Table 4. Sample solutions of Year 2 students to example exercise 1

\begin{tabular}{|l|l|}
\hline $\mathbf{7 5 0 g}+\mathbf{7 6 0} \mathrm{g}=750 \mathrm{~g}-50 \mathrm{~g}=700 \mathrm{~g}$ & Boy 1, Year 2 \\
$700 \mathrm{~g}+760 \mathrm{~g}=1460 \mathrm{~g}$ & \\
$=\mathbf{1 4 6 0} \mathrm{g}+\mathbf{5 0} \mathrm{g}=\mathbf{1 5 1 0 g}$ & Girl 1, Year 2 \\
\hline or $750 \mathrm{~g}+760 \mathrm{~g}=2 \times 700 \mathrm{~g}+110 \mathrm{~g}=1510 \mathrm{~g}$ & Boy 2, Year 2 \\
\hline or $750 \mathrm{~g}+760 \mathrm{~g}=2 \times 750 \mathrm{~g}+10 \mathrm{~g}=1510 \mathrm{~g}$ & \\
\hline
\end{tabular}

Table 5. Sample solutions of Year 3 student to example exercise 2

\begin{tabular}{|l|l|}
\hline $\mathbf{3 2 8}-\mathbf{1 6 2}=300-100=200$ & \\
$20-60=-40$ & Boy 3, Year 3 \\
$8-2=6$ & \\
$=\mathbf{2 0 0}-\mathbf{4 0}+\mathbf{6}=\mathbf{1 6 6}$ & \\
\hline
\end{tabular}

Table 6. Sample solutions of Year 2 student to example exercise 3

\begin{tabular}{|l|l|}
\hline $\mathbf{4 2 0}-\mathbf{8 0}=$ & \\
$80-20=60$ & Boy 4, Year 2 \\
$420-20=400$ & \\
$=\mathbf{4 0 0}-\mathbf{6 0}=\mathbf{3 4 0}$ & \\
\hline
\end{tabular}

\section{Visualizations - group work, Year 4}

As we can see in Table 7, multiplication can be visualized as calculating the area of a rectangle with many different variations that all depend on the originality of student thinking.

Table 7. Sample solutions of Year 4 students to example exercise 4

\begin{tabular}{|c|c|c|c|}
\hline $\begin{array}{l}36 \times 8=288, \text { because } \\
30 \times 5+6 \times 5+30 \times 3+3 \\
\text { or } 8 \times 40-8 \times 4=288, \\
\text { or } 8 \times 30+8 \times 6=288, \\
\text { or } 10 \times 40-2 \times 40-8 \times 4\end{array}$ & & & \\
\hline 30 & 6 & & 36 \\
\hline 5 & 8 & 8 & \\
\hline 3 & & & \\
\hline & & & 4 \\
\hline $\begin{array}{r}30 \times 5+6 \times 5+3 \\
G\end{array}$ & $=288$ & & $\begin{array}{r}\mathbf{8 x 4 0 - 8 x} \\
\text { Boy }\end{array}$ \\
\hline
\end{tabular}




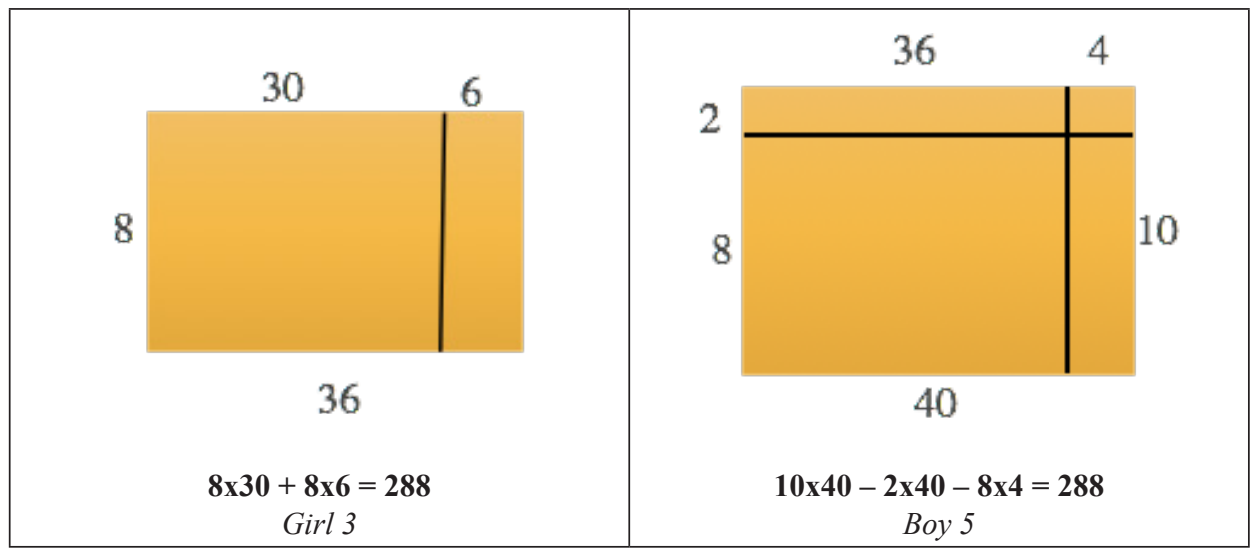

\section{Open-ended tasks - group work}

The students were given a dice game which gave rise to an opportunity to practice the skill of adding two addends (with one addend being the result from a thrown dice). Fast-paced pupils thought of extending the task into making pairs of numbers adding up to 100 .

The next lesson, we had another activity related to addition: trying to solve the equation $\_5+\ldots=100$ with one of the tens being supplied by a dice (e.g. a student would roll a 6 and the equation would become $55+\ldots=100$ to be solved for the second ten value). This time one of the students helped the rest of the Year 1 class by explaining how he approached the problem himself: "Oh, I know, I will count by five!"

\section{Discovering relationships - group work}

The story goes: a father would like to divide his 31 donkeys among the 4 of his children giving them, respectively, 1/3,1/4, 1/6 and 1/9 of the animals. He has a problem with this division. Then, a neighbour brings him 5 additional donkeys, and the problem is solved; what's more, the extra animals can then be returned to the neighbour. How is this possible?

The workings of Boy 6, Year 4:

31 is not a multiple of either $3,4,6$, or 9 - that's why the father has a problem at first $1 / 3$ of $36=12,1 / 4$ of $36=9,1 / 6$ of $36=6,1 / 9$ of $36=4$ - numbers of donkeys given away $12+9+6+4=31-$ altogether $36-31=5$ left

How it is possible: $1 / 3+1 / 4+1 / 6+1 / 9=12 / 36+9 / 36+6 / 36+4 / 36=31 / 36$, which is not equal to 1 .

For an alternative solution, see Figure 1. 


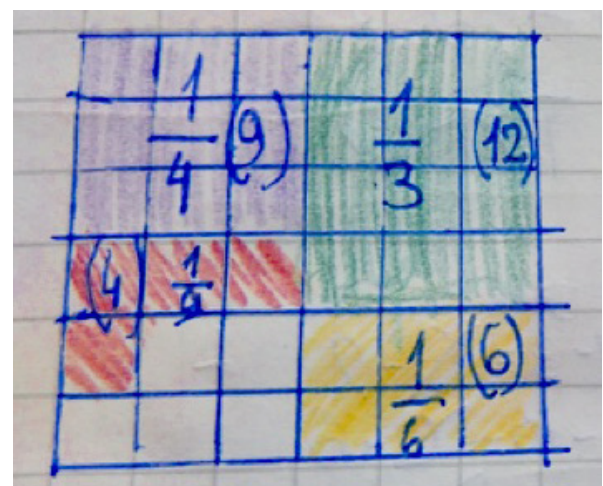

Figure 1. Sample solution of Girl 4, Year 4

One can easily observe the differences in approaching the task by the two students; if the first method seems to be more formal and precise, the second one strikes us with its beautiful simplicity.

\section{Searching for patterns, open-ended tasks - group work}

Looking for two numbers satisfying these conditions: $£ 1<\square_{1}, \square_{2}<£ 3, \square_{1}-\square_{2}=50 \mathrm{p}$

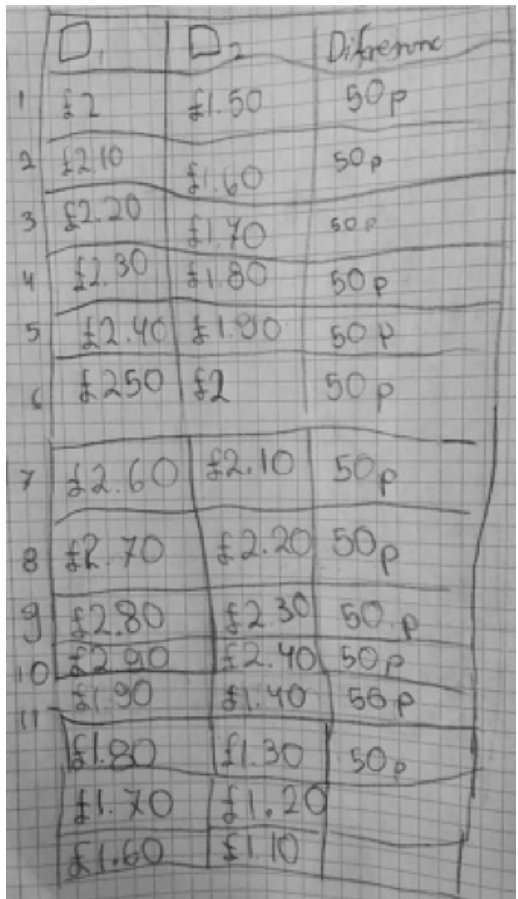

Figure 2. Sample solution of Boy 7, Year 3 
Above, we can see the analysis of a group that used a very systematic approach to the task - pupils presented all the possible pairs, from the two smallest to the two greatest numbers.

\section{Asking questions, sharing ideas, discovering relationships}

$40: 1 / 2+15=80+15=95$. These two students (Figures 3 and 4 ) were able to solve the task without having formal knowledge about division by a fraction.
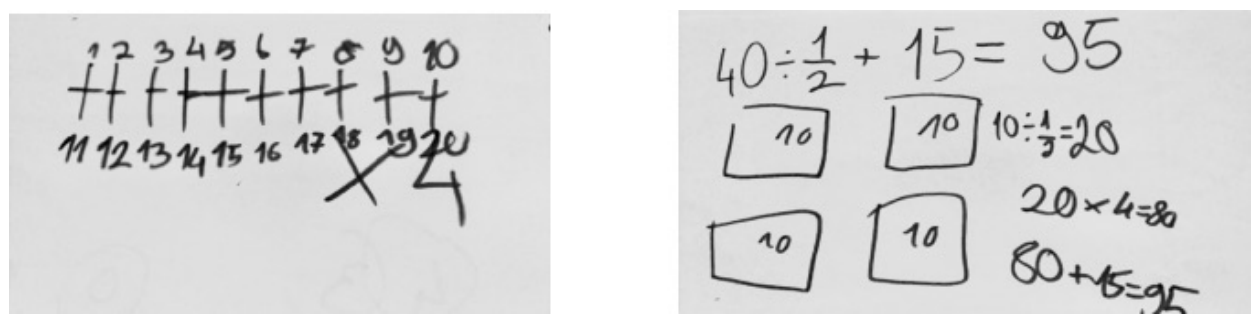

Figure 3. Sample solution of Girl 5, Year 4

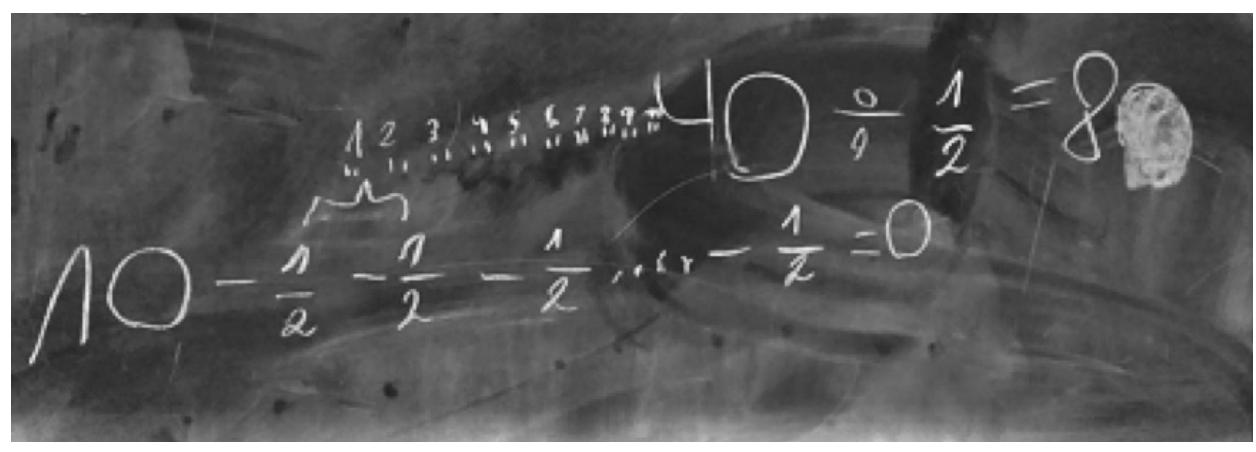

Figure 4. Sample solution of Boy 8, Year 3

Real-life word problems can be designed by children themselves. The following is an example of a task which was created when we discussed capacity. One of the students (Girl 6) thought of using containers of different sizes and obtaining 1 litre. These were the findings which were worked out together in the classroom with a second grader at the board leading the class discussion.

I: $3 \times 120 \mathrm{ml}=360 \mathrm{ml}, 1 \times 80 \mathrm{ml}=80 \mathrm{ml}, 1 \times 60 \mathrm{ml}, 360 \mathrm{ml}+80 \mathrm{ml}+60 \mathrm{ml}=500 \mathrm{ml}, 2 \times 500 \mathrm{ml}=1000 \mathrm{ml}=11$ II: $6 \times 120 \mathrm{ml}=720 \mathrm{ml}, 2 \times 30 \mathrm{ml}=160 \mathrm{ml}, 2 \times 60 \mathrm{ml}=120 \mathrm{ml}, 720 \mathrm{ml}+160 \mathrm{ml}+120 \mathrm{ml}=1000 \mathrm{ml}=11$ III: $3 \times 240 \mathrm{ml}=720 \mathrm{ml}, 1 \times 120 \mathrm{ml}=120 \mathrm{ml}, 2 \times 80 \mathrm{ml}=160 \mathrm{ml}, 720 \mathrm{ml}+120 \mathrm{ml}+160 \mathrm{ml}=1000 \mathrm{ml}=11$

Children need to be heard, as their voices in discovering mathematical concepts are unique, their freshness can give a humble teacher insight into the new ways of explaining 
"old" ideas and their courage and curiosity can change a teacher's perception of the complexity of problems that pupils can handle.

\section{Conclusion}

There is an urgent need to discuss and implement modern mathematical practices in early childhood education in Poland. These practices not only have the ability to deepen understanding and boost motivation among students, engage their emotions and make them feel responsible for their own learning, but also help teachers realize that mathematical language development can only take place if students are given a voice in mathematical discourse and discover mathematical concepts on their own. Closer cooperation is absolutely needed between the academia and teaching communities; both parties have much to learn from each other. Teachers can also learn from their students and be surprised by their remarkable abilities, which can be revealed when approached with faith by a humble adult. Opportunities for dialogue and discovery should be free from teachers' fear of losing authority. The dialogic approach to teaching can be very helpful in liberating both students and teachers as learners of mathematics.

\section{References}

Alexander R.J. (2017), Towards Dialogic Teaching: Rethinking Classroom Talk. York, Dialogos. Boaler J. (2016), Mathematical Mindsets: Unleashing Students Potential through Creative Math, Inspiring Messages, and Innovative Teaching. San Francisco, Jossey-Bass \& Pfeiffer Imprints.

Dąbrowski M. (2013), (Za) trudne, bo trzeba myśleć. Warszawa, Instytut Badań Edukacyjnych.

Dweck C.S. (2017), Mindset: Changing the Way You Think to Fulfil Your Potential. London, Robinson.

Gershon M. (2016), How to Develop Growth Mindsets in the Classroom: The Complete Guide. CreateSpace Independent Publishing Platform.

Humphreys C. and Parker R. (2015), Making Number Talks Matter Developing Mathematical Practices and Deepening Understanding, Grades 4-10. Portland, Stenhouse Publishers.

Lakatos I. et al. (1976), Proofs and Refutations: The Logic of Mathematical Discovery. Cambridge, Cambridge University Press.

Pehkonen E. (1999), Open-ended Problems: A method for an educational change. Proceedings of International Symposium on Elementary Maths Teaching. Prague, Charles University: SEMT 99.

Pólya G. (1988), How to Solve It: A New Aspect of Mathematical Method. Princeton, Princeton Univ. Press. 